\title{
Further Reflections on the "Postmodern Turn" in the Social Sciences: A Reply to William Outhwaite
}

\author{
Simon Susen ${ }^{1}$ \\ Published online: 28 July 2016 \\ (C) Springer Science+Business Media New York 2016
}

I am immensely grateful to William Outhwaite for commenting on my book The 'Postmodern Turn' in the Social Sciences (Basingstoke: Palgrave Macmillan, 2015). ${ }^{1}$ I should stress at the outset that I agree with most of the points he makes in his commentary, which I find very insightful, thought-provoking, and constructive. Hence, any reader expecting to be entertained by a cockfight between book author and book reviewer will be disappointed. Let me take this opportunity to reflect on some of the main issues raised in Outhwaite's inspiring review.

\section{"Definitive"}

I am not sure whether or not I have "produced what is surely the definitive account of postmodern social, political, and cultural theory", , but it seems to me that Outhwaite is certainly right to point out that most contemporary social scientists would agree with the contention that the postmodern era - if there has ever been such a thing — is "well and truly over"3. One may, or may not, share the view that the sustained concern with, and the heated debates on, the concept of "the postmodern" peaked in the mid-1990s ${ }^{4}$, as I maintain in the book, and that "around 1997 or so the tide started to turn" ${ }^{\text {, }}$ as asserted by Keith Tester in an interview he conducted with Zygmunt Bauman. ${ }^{6}$ Irrespective of the question of what one makes of this assessment, however, there is no point in denying that today, in the early twenty-first century, the concept of "the postmodern" is out of fashion, regarded by most social scientists as, at best, an outdated object of investigation belonging

\footnotetext{
${ }^{1}$ Susen (2015).

${ }^{2}$ Outhwaite (2016/2017) (italics added).

${ }^{3}$ Ibid.

${ }^{4}$ On this point, see Susen (2015), pp. 32 and 75.

${ }^{5}$ Bauman and Tester (2007), p. 25.

${ }^{6}$ See ibid.
}

Simon Susen

Simon.Susen@ city.ac.uk

1 City University London, Northampton Square, London EC1V 0HB, UK 
to the history of intellectual thought or, at worst, an esoteric subject of inquiry that never deserved to be taken seriously in the first place. I hope to have demonstrated in my book that the various paradigmatic transitions that have arguably been taking place in the social sciences over the past few decades should be reason enough to grapple with the numerous theoretical and practical implications of the "postmodern turn". If there is anything "definitive" about this study, it is the conclusion that the "postmodern spirit", notably in terms of its subtle spheres of influence, will be around for some time to come, even if the historical episode associated with it may long be over.

\section{"Paradoxical"}

In my view, Outhwaite is right to draw attention to the paradoxical nature of historical periodizations concerning the purported advent of "the postmodern". More specifically, Lyotard's claim ${ }^{7}$ - to which Outhwaite refers in his commentary - that "the postmodern" can be interpreted not only as "the successor to the modern" 8 but also, in a more fundamental sense, as "a precursor to it" is sociologically significant, implying that key features of the "postmodern condition" have always already been part of both modern and premodern life forms. In other words, even if post-traditional modes of existence associated with postmodernity are characterized by a radicalization of indeterminacy at unparalleled levels, this does not mean that indeterminacy cannot be regarded as a constitutive component of human modes of existence preceding those of the present.

As Outhwaite - citing Adorno - suggests, it may appear that the modern "lives on because the moment to realize it was missed" " - an insight that Adorno applied to the interpretation of the role of philosophy in the twentieth century. Yet, whereas sceptics may posit that, as Adorno notes, "philosophy [...] once seemed obsolete"11, even the most extreme advocates of postmodernity would find it difficult to provide conclusive evidence for the validity of the contention that modernity has completely disappeared from the historical stage. To the extent that modernity remains an "unfinished project"12, it continues to represent a societal condition of unfulfilled potential. This potential, however, constitutes a conglomerate of contradictory - that is, of both positive and negative, empowering and disempowering, emancipatory and repressive - forces. The paradox persists.

\section{"Independent"/“Interdependent"}

As Outhwaite rightly remarks, my book aims to examine the impact of the "postmodern turn" on the social sciences by disaggregating it into five paradigmatic transitions, which are characterized by the recognition of, and insistence upon, "the radical indeterminacy of all material and symbolic forms of existence" ${ }^{\text {": }}$ the "relativist turn" in epistemology, the "interpretive turn" in social

\footnotetext{
${ }^{7}$ On this point, see Lyotard (1986).

${ }^{8}$ Outhwaite (2016/2017) (italics added).

${ }^{9}$ Ibid. (italics added).

${ }^{10}$ Adorno (1973 [1966]), p. 3.

11 Ibid., p. 3.

12 See Habermas (1996 [1981]) and Habermas (1989 [1985/1987]). On modernity as an unfinished project, see also, for example: Frank (1992); Honneth et al. (1992a); Honneth et al. (1992b); McLellan (1992); Outhwaite (2009 [1994]), pp. 118-133; Outhwaite (1996), esp. pp. 305-365; Passerin d'Entrèves and Benhabib (1996); Patton (2001), esp. p. 11875; Susen (2007), p. 72; and Susen (2015), pp. 233-235, 241, and 279.

${ }^{13}$ Susen (2015), p. 1 (italics in original); on this formulation, see also ibid., pp. 39, 233, 258, and 278. In addition, see Outhwaite (2016/2017).
} 
research methodology, the "cultural turn" in sociology, the "contingent turn" in historiography, and the "autonomous turn" in politics. These presuppositional shifts are, at the same time, relatively independent and relatively interdependent.

- They are relatively independent, insofar as each of them has its own rationale, expressed in idiosyncratic disciplinary implications and consequences.

- They are relatively interdependent, insofar as they draw upon, and are influenced by, one another, while sharing "what Wittgenstein would have called a family resemblance"1

As argued in my book, one crucial trait that these paradigmatic turns have in common is their sustained concern with different degrees and forms of indeterminacy. One may have good reason to object to - or, instead, to sympathize with - (i) relativist conceptions of knowledge, (ii) interpretivist conceptions of social research, (iii) culturalist conceptions of society, (iv) non-determinist conceptions of history, and (v) autonomist conceptions of politics. Notwithstanding the respective merits and limitations of these paradigmatic positions, they have had, and continue to have, a major impact upon the normative parameters underlying large parts of both mainstream and alternative forms of investigation in the contemporary social sciences. As Outhwaite eloquently puts it, "the 'postmodern turn' has had the valuable consequence that it has sharpened our focus on a number of important features of the recent developments shaping modern societies" $" 15$, including the ways in which they are conceptualized by laypersons in their everyday lives as well as by social-scientific experts in their critical explorations.

\section{"Indeterminate"}

One of the ironies of the term indeterminacy is that, as Outhwaite perceptively observes, its meaning is itself indeterminate, or at least ambiguous. Its denotative and connotative meanings range 'from 'vagueness' or 'imprecision' to stronger and sometimes more formal notions of 'undecidability",16. In my opinion, Outhwaite's (hitherto) preference for the term fragmentation as "a common denominator to these postmodern turns" $" 17$ is entirely justified, not least because - along with "indeterminacy"-it represents one of the most striking characteristics of highly complex human life forms. Unsurprisingly, different commentators have different views about the usefulness of epochal labels — such as "modern", "late modern", or "postmodern"aimed at capturing the historical specificity of the current era. Irrespective of one's assessment of these descriptions, it is no accident that fragmentation constitutes one of the predominant tendencies examined, and frequently bemoaned, by contemporary critical sociologists. Indeed, the increasing fragmentation of key civilizational - notably social, cultural, political, economic, geographic, demographic, epistemic, and experiential — dimensions of human life forms appears to contribute to the gradual disintegration of elements that play a pivotal role in the flourishing of the human condition. ${ }^{18}$

Some readers will agree, and others will disagree, with Outhwaite's verdict that the term indeterminacy is "probably the best way of representing a common denominator to these

\footnotetext{
$\overline{14}$ Outhwaite (2016/2017) (italics removed from "family resemblance").

${ }^{15}$ Ibid. (italics added).

${ }^{16}$ Ibid. In this context, Outhwaite makes reference to Gödel (1931).

${ }^{17}$ Outhwaite (2016/2017).

${ }^{18}$ Outhwaite mentions the fragmentation of work and of family relations as two examples. See ibid.
} 
postmodern turns - better, perhaps, than the notion of 'fragmentation', which [he has tended] to use to explain them" 19 . One may add to this judgement that, paradoxically, fragmentation processes are as much about determinacy as they are about indeterminacy. In terms of determinacy, fragmentation processes may follow causally defined and relatively predictable patterns of development, in accordance with context-specific logics of social functioning. In terms of indeterminacy, fragmentation processes may constitute fairly open and rather unpredictable dynamics, emerging from-while also triggering - unintended consequences. The challenge of living with different degrees and forms of determinacy and indeterminacy lies at the core of our everyday lives.

\section{"Ambivalent"}

Undoubtedly, it is difficult to make sense of modernity without accounting for the extent to which it is marked by different levels of ambivalence. ${ }^{20}$ On the one hand, there is a dark modernity, whose repressive facets cannot be dissociated from the socio-historical preponderance of instrumental reason. On the other hand, there is a bright modernity, whose emancipatory aspects have been brought about, as well as grasped, by the discursive force of critical reason. The former "are intimately associated with variations of control - such as power, authority, order, discipline, obedience, enclosure, and heteronomy - and materialize themselves in social processes of domination, regulation, exploitation, alienation, fragmentation, exclusion, and discrimination" 21 . The latter "are expressed in Enlightenment ideals - such as progress, tolerance, liberty, equality, solidarity, dignity, sovereignty, and autonomy - and manifest themselves in social processes of liberation, self-determination, and unification" 22 .

Outhwaite and I seem to agree on the sociological centrality of this ambivalence. As noted by Outhwaite, the conceptual antithesis of "liberty" and "discipline"23 captures this duality in an analytically powerful manner, obliging us to resist any temptation to reduce modernity either to its empowering or to its disempowering dimensions. ${ }^{24}$ In fact, the overly pessimistic narrative that converts the whole of modernity into "a caricature of totalizing reason" 25 , portraying it as a completely or at least "tendentially totalitarian" $26 \mathrm{era}$, is as problematic as the excessively optimistic narrative that presents the whole of modernity as an emancipatory expression of the Kantian trinity of Verstand, Vernunft, and Urteilskraft, giving the misleading impression that it is tantamount to a pristine condition of universal enlightenment. Both the spirit and the reality of modernity have illustrated, time and again, that it is by recognizing the tension-laden confluence, rather than the artificial separation, of the bright and the dark sides of contemporary history that

\footnotetext{
19 Ibid.

${ }^{20}$ On this point, see Susen (2015), pp. 16-18. See also ibid., pp. 1, 16-22, 44, 75, 113, 119, 143, 174, 178, 179, $180,190,191,204,205,219,223,235,236,269,273,276,279$, and 285n86. On the social and political challenges arising from the experience of ambivalence under modern and/or postmodern conditions, see, for instance: Bauman (1991); Bauman and Tester (2007), esp. pp. 23-25 and 29; Hammond (2011), pp. 305, 310, 312, and 315; Iggers (2005 [1997]), pp. 146-147; Jacobsen and Marshman (2008), pp. 804-807; Kellner (2007), p. 117; Mulinari and Sandell (2009), p. 495; Quicke (1999), p. 281; Susen (2010), esp. pp. 62-78; and van Raaij (1993), esp. pp. 543-546, 551-555, and 559-561.

${ }^{21}$ Susen (2015), p. 17.

22 Ibid., p. 17.

${ }^{23}$ See Wagner (1994).

24 On this point, see Adorno and Horkheimer (1997 [1944/1969]).

${ }^{25}$ Outhwaite $(2016 / 2017)$.

26 Ibid.
} 
critical theory can contribute to a balanced - and, hence, plausible - understanding of the contradictory forces that have shaped, and continue to shape, human lifeworlds in communicatively sustained, yet systemically colonized, interactional formations.

\section{"Transcendental"/“'Open-Ended"}

Making reference to Jack Nusan Porter's attempt to respond to the question of whether or not sociology is "dead" 27 , Outhwaite examines the cogency of the following twofold answer to this interrogation:

- If understood as a grand theory, or a set of catch-all explanatory frameworks with ambitious macro-conceptual pretensions, the answer is yes.

- If understood as an open-ended impulse to develop a critical understanding of different aspects of human society, comprising the ways in which our understanding of it is constantly being redefined, the answer is no.

Outhwaite has argued elsewhere ${ }^{28}$, and reiterated in his review of my book ${ }^{29}$, that most of social theory is closer to the latter position than to the former. He makes it clear that, as a result, he has serious doubts about the validity of my claim that, in recent decades, we have been witnessing a "crisis of the universalist ambitions of modern social theory"30, which "is inextricably linked to the

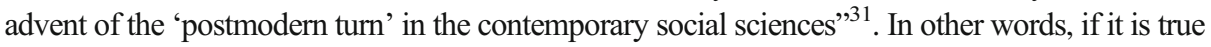
that most — including most prominent— social theorists have always conceived of their project as a critical endeavour, irreducible to the attempt to provide simplistic big-picture accounts of highly complex realities, then it is misleading to make provocative announcements about the alleged crisis of the ostensibly universalist spirit running through the construction of sociological toolkits. Outhwaite, in support of this assertion, draws attention to founding figures of sociology (that is, Marx, Durkheim, Weber, and Simmel), all of whom - in his view-succeeded in "offering the social-scientific equivalent of transcendental arguments in philosophy: open-ended attempts to

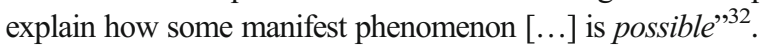

The question that poses itself in this context, however, is to what extent it is possible to reconcile "the transcendental" and "the open-ended" without falling into the trap of a merely rhetorical commitment to recognizing two key aspects of social life:

- on the one hand, the species-constitutive presence, and socio-ontological significance, of foundational - and, hence, cross-culturally valid - elements of human existence, whose anthropological centrality transcends the spatiotemporal boundaries of civilizational specificity;

- on the other hand, the species-constitutive presence, and socio-ontological significance, of contextual - and, thus, culturally contingent - elements of human existence, whose anthropological centrality depends on the spatiotemporal boundaries of civilizational specificity.

\footnotetext{
${ }^{27}$ See Porter (2008), p. viii. On this issue, see also Susen (2015), p. 6.

${ }^{28}$ See Outhwaite (1999).

${ }^{29}$ See Outhwaite $(2016 / 2017)$.

${ }^{30}$ Susen (2015), p. 6.

${ }^{31}$ Ibid., p. 6.

32 Outhwaite (2016/2017) (italics in original) (spelling modified).
} 
Social theorists - and, in a broader sense, social philosophers - have grappled with this tension for a long time; it is far from obvious, however, to what degree this tension can, or even should, be resolved. It seems to me that the paradigmatic transition from the (arguably modern) preoccupation with relative determinacy ${ }^{33}$ to the (arguably postmodern) concern with radical indeterminacy ${ }^{34}$ has shifted the investigative parameters from the search for foundational and cross-culturally valid to the exposure of contextual and culturally contingent elements of human existence.

Surely, most - if not, all - constitutive social phenomena are characterized by both the former and the latter. As I have sought to demonstrate in another book ${ }^{35}$, all human life forms are crucially shaped by at least five socio-ontological foundations: labour, language, culture, desire, and experience. ${ }^{36}$ In terms of their role and constitution, however, these socioontological foundations vary substantially across time and space, acquiring different functions, and reaching different levels of development, in different modes of existence. In brief, both "the foundational" and "the contingent" are built into the human condition. Social life is marked, and shaped, by both the contingency of foundations and the foundations of contingency. It is the task of sociological research to explore the relationship between the foundational and the contextual elements of human existence. Given that this relationship is shot through with - to use Outhwaite's terminology_-both transcendental and open-ended processes and structures, this task cannot be dissociated from the challenge of shedding light on the relationship between determinacy and indeterminacy. ${ }^{37}$

\section{"Critical Realist"}

The thematic overlap between postmodern thought and other perspectives may not always be immediately obvious. One central area of investigation in which the intersection between postmodern and alternative variants of social analysis is evident, however, is epistemology. In line with this insight, Outhwaite makes reference to Roy Bhaskar's critical realism ${ }^{38}$, which urges us to concede that "reality, even to a considerable extent social reality, is as it is, independent of our descriptions" 39 , while insisting that "we can know it only under particular descriptions and that these are inevitably changing, open-ended, and contentious" 40 . If we accept this twofold presuppositional framework by subscribing to both realism ("reality does exist") and criticism ("we need to be critical of our material and symbolic constructions of reality"), then - as Outhwaite reminds us - "we have gone a long way to meeting the claims of postmodernism"41, notably its advocacy of epistemological scepticism, which, in this case, is conceptually embedded in a radicalized version of social constructivism. Rather than

\footnotetext{
$\overline{33}$ On this point, see Susen (2015), pp. 1, 39, 48, 65, 72, 74, 92, 233, 258, 265, and 278.

${ }^{34}$ On this point, see ibid., pp. 1, 9, 19, 39, 48, 59, 65, 66, 69, 72, 74, 82, 90, 92, 93, 104, 137, 138, 139, 166, 180, $233,258,264,265,268$, and 278.

35 Susen (2007).

${ }^{36}$ On this point, see ibid., Chapter 10.

${ }^{37}$ On this point, see Susen (2015), pp. 1, 9, 19, 39, 48, 59, 65, 66, 69, 72, 74, 82, 90, 92, 93, 104, 137, 138, 139, $166,180,233,258,264,265,268$, and 278.

${ }^{38}$ See, for instance: Archer et al. (1998); Bhaskar (2011a [1989]); Bhaskar (2011b [2002]); and Bhaskar (2012 [2002]).

${ }^{39}$ Outhwaite (2016/2017) (italics in original).

${ }^{40}$ Ibid. (italics added).

41 Ibid.
} 
stubbornly demonizing or naïvely embracing postmodern thought, we need to acknowledge that it may be both theoretically and practically fruitful to identify its main intellectual contributions to the contemporary social sciences, including areas of inquiry that have been sources of intense dispute for centuries.

\section{"Narrative"}

According to Outhwaite, the principal achievement of my book is "to document, with meticulous accuracy and precision, the vast variety of ways in which social theory has responded to these changes" unprecedented degrees of indeterminacy and fragmentation - "in the course of the toand-fro over "the postmodern",43. In such a climate, "political ideologies are boiled down into sound-bites and flavours" 44 , dispersed within a rainbow-like assemblage of competing narratives, none of which can claim to possess a discursive monopoly on the interpretation of reality. In the contemporary era, highly differentiated societies lack a processual, let alone a structural, epicentre. Outhwaite posits, with a healthy dose of irony, that "[w]e are, in a sense, all populists now" 45 . In the jungle world of commodified eclecticism, we are able to choose from a large variety of lifestyle-related options and diffusely organized worldviews. In such a polycentric - or, if one prefers, centrelessenvironment of ubiquitous plurality, all narratives - regardless of whether they may be classified as "micro" or "macro", "minor" or "major", "mini" or "maxi", "contingent" or "foundational"- compete in an open market of the "anything-goes-world"

\section{"Fishy"}

Outhwaite's most significant—and, in my view, at least partly justified—criticism "is that in casting [my] trawling net so broadly (including-rather problematically-Nietzsche, Heidegger, and Wittgenstein), [I tend] to occlude the role of some of the bigger explicitly postmodernist and/or poststructuralist fish (including, perhaps, Stanley Fish)"47. Although, in Outhwaite's eyes, Jean-François Lyotard and Jean Baudrillard receive the attention they deserve, other "high flyers" whose names are rightly or wrongly associated with la vague postmoderne - such as Bruno Latour, Michel Maffesoli, Gianni Vattimo, Judith Butler, and Fredric Jameson-do not figure as "first-league game changers" and are largely relegated to footnotes. Let me, in response to this observation, make two straightforward points.

\footnotetext{
42 Ibid.

43 Ibid.

${ }^{44}$ Ibid. (spelling modified).

45 Ibid.

${ }^{46}$ Susen (2015), p. 32. On this point, see also ibid., pp. 117, 193, 194, 211, 252, 280, and 286n134. On the slogan “anything goes", see, for instance: Beck and Lau (2005), pp. 540-554; Boghossian (2006), p. 23; Butler (2002), pp. 35; Clicqué (2005), esp. p. 29; Cole (2003), p. 493; Eickelpasch (1997), pp. 18-19; Elliott (2007 [2001]), p. 141; Gane and Gane (2007), p. 131; Matthewman and Hoey (2006), p. 536; Mcevoy (2007), p. 399; Nola and Irzik (2003), p. 395; Rose (1991), pp. 3 and 60; Sokal and Bricmont (1998), pp. 78-85; Torfing (1999), pp. 275-276; and van Raaij (1993), p. 560.

${ }^{47}$ Outhwaite (2016/2017) (italics added).
} 
First, as spelled out in the section entitled "A Methodological Problem" " " "[t]he theoretical exploration of the 'postmodern turn' undertaken in this book is based on a thematic, rather than an author-focused, examination"49. To be exact, my study has sought to offer an "aspectoriented account of postmodern thought" ${ }^{, 50}$ by focusing on five areas of concern: epistemology, methodology, sociology, historiography, and politics. Drawing attention to both the advantages and the disadvantages of such a - thematically guided - form of inquiry, the book contains a somewhat self-critical section, which comprises the following explanation:

Paradoxically, the main strength of an aspect-oriented analysis is, at the same time, its major weakness. Its strength lies in its capacity to illustrate the thematic complexity of the "postmodern turn". Its weakness, however, consists in its tendency to over-generalize. It is human beings - that is, individual thinkers, authors, and researchers - who stand behind the issues discussed in a thematically organized volume. Hence, to structure the argument in accordance with the five aforementioned areas of concern and, furthermore, take them to represent the most striking features of an overall paradigmatic shift means to impose a sense of consistency and homogeneity on a remarkably amorphous and heterogeneous landscape of paradigmatic transitions and contradictions. In other words, the risk of making overgeneralizations, resulting from the attempt to provide a thematically structured overview of an internally diversified and fragmented intellectual movement, constitutes a serious - albeit not untenable - methodological limitation of the foregoing enquiry. ${ }^{51}$

The paragraph cited above is not meant to serve as an excuse for what harsh critics may conceive of as an indefensible inadequacy. It makes clear, however, that the aspect-oriented, rather than author-focused, analytical undertaking of my book does not aim to offer a detailed discussion of original contributions made by individual scholars to postmodern thought. To put it bluntly, the study seeks to accomplish what it says on the tin: namely, to provide an in-depth aspect-oriented - and, thus, thematically structured - investigation into the impact of the "postmodern turn" on the contemporary social sciences.

Second, the section entitled "Who are These "Postmodernists?"52 provides a detailed account of a "list of scholars whose works are - directly or indirectly, explicitly or implicitly, rightly or wrongly - associated with the rise of postmodern thought" ${ }^{\text {"53 }}$. With the exception of Stanley E. Fish, all of the thinkers mentioned by Outhwaite in this context are not only included in this section but also examined and classified in terms of their importance for a comprehensive understanding of the "postmodern turn". Of course, one may have good reason to disagree with the book's assessment of their respective significance, especially in relation to point number 12, which categorizes these thinkers in terms of their intellectual influence (dividing them into three categories: "highly influential", "very influential", and "influential"). ${ }^{54}$ With the exception of Vattimo, all of the intellectuals mentioned by Outhwaite are classified as "very influential" (and "very prominent contemporary scholars"), and their works are extensively referred to throughout the book. Hence, although it is true that, in this study, the

\footnotetext{
${ }^{48}$ See Susen (2015), p. 232.

${ }^{49}$ Ibid., p. 232 (italics in original).

${ }^{50}$ Ibid., p. 232 (italics added).

51 Ibid., p. 232 (italics in original).

${ }^{52}$ See ibid., pp. 22-31.

53 Ibid., p. 22.

${ }^{54}$ On this point, see ibid., p. 31.
} 
Anglo-American literary theorist Stanley E. Fish is relegated to a footnote ${ }^{55}$, I am not sure to what extent it is accurate to affirm that I "occlude" aforementioned thinkers in the postmodern endeavour.

More importantly, however, Outhwaite is, I believe, right to suggest that my book-while drawing attention to the fact that "most of the relevant thinkers are French or, secondarily, North American"57_ "does not [...] say much about the underlying dynamics" ethnocentric constitution of postmodern scholarship. Indeed, similar to poststructuralism, postmodernism "was a largely French product but one which was more successful in its export version than at home" the discursive domain of their Francophone counterparts, which had generated most of the "celebrity chefs" 60 responsible for the postmodern menu. Perhaps, then, another book needs to be written to shed light on the socio-historical conditions underpinning the production of postmodern thought in different parts of the world. Certainly, this would be an ambitious task, but one worth pursuing.

\section{Une fin sans fin...}

William Outhwaite has done a brilliant job in providing a remarkably balanced and generous account of a book that, I am sure, suffers from various significant limitations and shortcomings, not least due to its ambitious nature. As, I hope, my study has demonstrated on several levels, the key facets of the "postmodern turn" are of paramount importance to the contemporary social sciences and will continue to shape their development in the future.

\section{References}

Adorno, T. W. (1973 [1966]). Negative dialectics, trans. E. B. Ashton. London: Routledge.

Adorno, T. W., \& Horkheimer, M. (1997 [1944/1969]). Dialectic of enlightenment, trans. John Cumming. London: Verso.

Archer, M., Bhaskar, R., Collier, A., Lawson, T., \& Norrie, A. (Eds.) (1998). Critical realism: essential readings. London: Routledge.

Bauman, Z. (1991). Modernity and ambivalence. Cambridge: Polity.

Bauman, Z., \& Keith, T. (2007). On the postmodernism debate. In P. Goulimari (Ed.), Postmodernism. What moment? (pp. 22-31). Manchester: Manchester University Press.

Beck, U., \& Lau, C. (2005). Second modernity as a research agenda: theoretical and empirical explorations in the "meta-change" of modern society. British Journal of Sociology, 56(4), 525-557.

Bhaskar, R. (2011 [1989]). Reclaiming reality: a critical introduction to contemporary philosophy, with a new introduction by Mervyn Hartwig. London: Routledge.

Bhaskar, R. (2011 [2002]). Reflections on metareality: transcendence, emancipation and everyday life, with a new introduction by Mervyn Hartwig. London: Routledge.

Bhaskar, R. (2012 [2002]). The philosophy of metareality: creativity, love, and freedom, with a new introduction by Mervyn Hartwig. London: Routledge.

Boghossian, P. A. (2006). Fear of knowledge: against relativism and constructivism. Oxford: Clarendon.

Butler, C. (2002). Postmodernism: a very short introduction. Oxford: Oxford University Press.

Clicqué, G. M. (2005). "Anything goes?" Theology and science in a culture marked by postmodern thinking. European Journal of Science and Theology, 1(2), 27-33.

\footnotetext{
55 See ibid., p. $314 n 72$.

${ }^{56}$ Outhwaite (2016/2017) (italics added).

${ }^{57}$ Ibid. On this point, see Susen (2015), pp. 23-24.

${ }^{58}$ Outhwaite (2016/2017) (italics added).

59 Ibid

${ }^{60}$ Ibid.
} 
Cole, M. (2003). Might it be in the practice that it fails to succeed? A Marxist critique of claims for postmodernism and poststructuralism as forces for social change and social justice. British Journal of Sociology of Education, 24(4), 487-500.

Eickelpasch, R. (1997). "Kultur" statt "Gesellschaft"? Zur kulturtheoretischen Wende in den Sozialwissenschaften. In C. Rademacher, \& G. Schweppenhäuser (Eds.), Postmoderne Kultur? Soziologische und philosophische Perspektiven (pp. 10-21). Opladen: Westdeutscher Verlag.

Elliott, A. (2007 [2001]). Concepts of the self, 2nd edition. Cambridge: Polity.

Frank, A. W. (1992). Only by daylight: Habermas's postmodern modernism. Theory, Culture \& Society, 9(3), 149-165.

Gane, M., \& Gane, N. (2007). The postmodern: after the (non-)event. In P. Goulimari (Ed.), Postmodernism. What moment? (pp. 127-138). Manchester: Manchester University Press.

Gödel, K. (1931). Über formal unentscheidbare Sätze der Principia Mathematica und verwandter Systeme. Monatshefte für Mathematik und Physik, 38, 173-198.

Habermas, J. (1989 [1985/1987]). The new conservatism: cultural criticism and the historians' debate, trans. Shierry Weber Nicholsen. Cambridge: Polity.

Habermas, J. (1996 [1981]). Modernity: an unfinished project. In M. Passerin d'Entrèves, \& S. Benhabib (Eds.), Habermas and the unfinished project of modernity (pp. 38-55) trans. Nicholas Walker, Cambridge: Polity.

Hammond, P. (2011). Simulation and dissimulation. Journal of War and Culture Studies, 3(3), 305-318.

Honneth, A., McCarthy, T., Offe, C., \& Wellmer, A. (Eds.). (1992a). Philosophical interventions in the unfinished project of enlightenment. Cambridge: MIT Press.

Honneth, A., McCarthy, T., Offe, C., \& Wellmer, A. (Eds.). (1992b). Cultural-political interventions in the unfinished project of enlightenment. Cambridge: MIT Press.

Iggers, G. G. (2005 [1997]). Historiography in the twentieth century: from scientific objectivity to the postmodern challenge, New Edition. Middletown, Con.: Wesleyan University Press.

Jacobsen, M. H., \& Marshman, S. (2008). Bauman's metaphors: the poetic imagination in sociology. Current Sociology, 56(5), 798-818.

Kellner, D. (2007). Reappraising the postmodern: novelties, mapping and historical narratives. In P. Goulimari (Ed.), Postmodernism. What moment? (pp. 102-126). Manchester: Manchester University Press.

Lyotard, J.-F. (1986). Le postmoderne expliqué aux enfants : correspondance, 1982-1985. Paris: Galilée.

Matthewman, S., \& Hoey, D. (2006). What happened to postmodernism? Sociology, 40(3), 529-547.

Mcevoy, J. G. (2007). Modernism, postmodernism and the historiography of science. Historical Studies in the Physical and Biological Sciences, 37(2), 383-408.

McLellan, D. (1992). The enlightenment project revisited. In S. Hall, D. Held, \& A. G. McGrew (Eds.), Modernity and its futures (pp. 327-377). Cambridge: Polity in association with the Open University.

Mulinari, D., \& Sandell, K. (2009). A feminist re-reading of theories of late modernity: Beck, Giddens and the location of gender. Critical Sociology, 35(4), 493-508.

Nola, R., \& Irzik, G. (2003). Incredulity towards Lyotard: a critique of a postmodernist account of science and knowledge. Studies in History and Philosophy of Science, 34(2), 391-421.

Outhwaite, W. (Ed.). (1996). The Habermas reader. Cambridge: Polity.

Outhwaite, W. (1999). The myth of modernist method. European Journal of Social Theory, 2(1), 5-25.

Outhwaite, W. (2009 [1994]). Habermas: a critical introduction, 2nd Edition, Cambridge: Polity.

Outhwaite, W. (2016/2017). Remarks on Simon Susen's The 'postmodern turn' in the social sciences. International Journal of Politics, Culture, and Society. doi:10.1007/s10767-016-9229-3.

Passerin d'Entrèves, M., \& Benhabib, S. (Eds.) (1996). Habermas and the unfinished project of modernity. Cambridge: Polity.

Patton, P. (2001). Postmodernism: philosophical aspects. In N. J. Smelser, \& P. B. Baltes (Eds.), International encyclopedia of the social \& behavioral sciences (pp. 11872-11877). Oxford: Elsevier.

Porter, J. N. (2008). Is sociology dead? Social theory and social praxis in a post-modern age. Lanham: University Press of America.

Quicke, J. (1999). The postmodern turn: problems and possibilities. British Journal of Sociology of Education, 20(2), 281-284.

Rose, M. A. (1991). The post-modern and the post-industrial: a critical analysis. Cambridge: Cambridge University Press.

Sokal, A., \& Bricmont, J. (1998). Fashionable nonsense: postmodern intellectuals' abuse of science. New York: Picador.

Susen, S. (2007). The foundations of the social: between critical theory and reflexive sociology. Oxford: Bardwell Press.

Susen, S. (2010). Meadian reflections on the existential ambivalence of human selfhood. Studies in Social and Political Thought, 17, 62-81.

Susen, S. (2015). The 'postmodern turn' in the social sciences. Basingstoke: Palgrave Macmillan.

Torfing, J. (1999). New theories of discourse: Laclau, Mouffe and Žižek. Oxford: Blackwell.

van Raaij, W. F. (1993). Postmodern consumption. Journal of Economic Psychology, 14(3), 541-563.

Wagner, P. (1994). A sociology of modernity: liberty and discipline. London: Routledge. 